\title{
A Transnational Perspective of Emma Goldman's Evolution as an Anarcha-Feminist
}

\author{
John David Bies \\ Department of History, Political Science, Philosophy \& American Studies, University of South Carolina-Upstate, Spartanburg South \\ Carolina, USA
}

Email address:

johnbies@bellsouth.net

\section{To cite this article:}

John David Bies. A Transnational Perspective of Emma Goldman's Evolution as an Anarcha-Feminist. History Research. Vol. 7, No. 1, 2019, pp. 7-16. doi: 10.11648/j.history.20190701.12

Received: June 21, 2019; Accepted: July 18, 2019; Published: August 13, 2019

\begin{abstract}
One of the foremost American anarchists of the early twentieth century was Emma Goldman who fought for the rights of working-class men and women. Upon her arrival in the US from the Lithuanian region of the Tsarist Russian Empire, she immediately became actively involved in the American Anarchist Movement. Initially she professed and involved herself in the violent overthrow of the government and its institutions and the selective assassination of exploitative leaders in industry and government. After her imprisonment, she found another avenue for her anarchical beliefs in the form of women's issues that included freedom of choice in marriage, and control over decision-making relative to her own body - issues that resonate today. This article, then, analyses her concentrated fight for women egalitarianism that has been described as the first vestiges of Anarcha-feminism. It is argued that her evolution towards feminist causes can be explained via three "Geo-moments" that was used to illustrate how her political beliefs progressed from Russian Nihilism, to violent Anarchism, and finally to Anarcha-feminism. The three Geo-moments employed in this study were: first, her experiences as a young Nihilist under Tsarist Russian rule; second, her arrival in the United States and introduction to American Anarchism; and lastly, her medical training as a nurse at the University of Vienna that gave rise to her views of feminism. As an Anarcha-feminist, she addressed and fought for women's rights to use birth control to decide how many children they wanted and fought against the female discriminatory aspects of the Comstock Law. In connection to her newly acquired medical education, Goldman has been identified as one of the initial supporters of the LGBT community, their issues and acceptance into society. Lastly, was her founding the founding of the periodical Mother Earth that served as a platform for her fight for female equality.
\end{abstract}

Keywords: Emma Goldman, Transnationalism, Anarcha-Feminism, Women's Rights

\section{Introduction}

Nowhere is woman treated according to the merit of her work, but rather as a sex Thus it is merely a question of degree whether she sells herself to one man, in or out of marriage, or to many men. [1] Emma Goldman (1911).

This quotation is a good example of how Emma Goldman saw the plight of women that influenced her view and position in history as perhaps the primogenitor of anarchafeminism. Though she is recognized as a first-rate anarchist and activist, Goldman can also be considered a theoretical contributor to the feminist movement during the first half of the twentieth century. Throughout her years of demonstrating and protesting the second-class status of women in society, Goldman was publicly labelled a dangerous anarchist, socialist, and communist; often gaining the newspaper moniker of "Red Emma". Emma Goldman was born in 1869 into a lower class Orthodox Jewish family in the Russian partitioned territory of Lithuania. At home, she faced abuse by her father, Abraham Goldman (1845-1909), who had refused to support her desire to continue her education believing that all a Jewish girl needed was to be a good wife, mother, and housekeeper. [2]

Goldman first became exposed to the concepts of anarchy during the Russian Nihilist Movement that rejected all forms of authority and supported the violent opposition and overthrow of Russia's tsarist monarchy. At the age of sixteen and against the wishes of her father, she immigrated to the US with her older step-sister and immediately became involved in labour union activities and the American 
Anarchist Movement. During this time, she personally witnessed the denigratory conditions that men, and especially women, faced in the workplace and the sub-standard medical care that was available to the lower working class. Eventually, Goldman was at the forefront of anti-war protestations, most notably the US entry into the First and Second World Wars. At the core of her activism, however, was her fight for an egalitarian position of women in the workplace, society, and home that was illustrated in several important essays where she addressed the "hypocrisy" of society when it came to the rights and aspirations of women. [3]

\section{Methodological Approach and Ideological Concepts}

There has been little historical research into the transformation of Goldman's thoughts from Anarchism and Nihilism to anarcha-feminism. The evolutionary path of Emma Goldman began in St. Petersburg and culminated with her studies at the University of Vienna in the late $1890 \mathrm{~s}$. It was therefore the intent of this study to analyse and describe Goldman's progression to an anarcha-feminist by employing a transnational methodology within the domain of three "Geo-moments." [4] The first Geo-moment included her experiences in St. Petersburg working as a young seamstress and participation in the Russian Nihilist Movement. The second Geo-moment encompassed her work as an anarchist and fledging feminist in the US. The last Geo-moment was the influence that her medical studies at the University of Vienna had upon various feminist, lesbian and gay controversies.

Within the context of this study, two research questions were addressed:

1. To what extent is it possible to delineate an evolutionary progression through the three "Geomoments" of Emma Goldman's development and maturation as an anarcha-feminist?

2. How did Emma Goldman use anarchical and socialist dialectics to justify and support her ideas and activism as an anarcha-feminist?

The process of Emma Goldman's evolution as an anarchafeminist required an analysis of the nature of transnationalanarchism within the context of her protestations and writings. The first factor in this equation required the application of a transnational approach, via Geo-moments, to study the development of her ideological convictions. The primary source materials used for this problem included Emma Goldman's two volume autobiography Living My Life, her essays and articles, pamphlets, and personal letters. The analysis of Emma Goldman's transformation from Nihilism to anarcha-feminism employed a transnationalist methodology. Simply put, transnational analysis incorporates the study of "cross border flows" to help explain various types of phenomena, it is "the interconnectedness of human history as a whole ay [ing] attention to network processes, beliefs, and institutions that transcend politically defined spaces." [5]

In a study of the global expansion of the women's movements [6] it was found that feminist theories and movements are often ignore the free flow of ideas across national boundaries; and secondly, that the importance and relevance of transnational actors in movements such as Anarchism, Socialism, and Feminism have been largely ignored. [7] An examples of the applicability of transnationalism was Owen's use of transnational analyses to explain how radical Islam's ideological struggle "flowed" beyond national borders; [8] additionally Goebel illustrated that the spread of communism into Mexico's political arena was the product of the transnational movement of the ideas of the Indian revolutionary Manabendra Nath Roy. [9] Finally, Bies [10] effectively made use of transnationalism to illustrate and explain how the political theory of Rosa Luxemburg evolved through cross-border flows.

Another significant reason for using transnationalism was its usefulness in analysing Goldman's personal interactions within and between members of the Jewish and non-Jewish community. The view that "transnationalism has become an increasingly important analytical category in American history [where] Jews acted as the quintessential transnational migrants." [11] provides further support and relevance for the use of this methodology. Additionally, Basu [12] described the progress of the women's movement by employing a transnational "mapping" technique. Her "mapping" did not incorporate drawn "maps," instead written geographical descriptions were used.

\section{Judaism and Anarchism}

There is no indication that Emma Goldman was a practicing Jew, even though her step-father was a practicing ultra-conservative Orthodox Jew. At best, she can be best described as an "ethnic" or "cosmopolitan" Jew, since there are indications that her feminist views were negatively viewed by traditional Jews even though many "Jewish women [were] so disdainful of an ultra-conservatism which styles itself as Jewish-friendly." [13] From a transnational perspective, Goldman's expectations of a better life in the US were eventually quashed when she experienced and observed the exploitative working conditions that women experienced within the garment industry's manufacturing sector. In fact, her involvement in anarchist unionism in New York was influenced by her awareness as a Jewess from Kovno (Kaunas, Lithuania) Russia of how progressivism supported the equality of men and women in Eastern-Europe. [14].

To say that her Jewishness played no role in her life would be incorrect, for she not only spoke in Yiddish to assembled Jewish crowds, but also included Yiddish stories as editor of Mother Earth. "As an adherent to anarchism she considered the state to be a coercive force that destroyed genuine freedom in its role of creating conformity but, in her emphasis on universalism, did not cast off her Jewish identity." [15] Throughout her adult life, she maintained a personal network of Jewish friends, anarchist, and feminist 
compatriots that transcended national politics. It is quite possible that the ideas of the Haskalah, or Jewish Enlightenment, were known to Goldman, due to the fact that growing up in the progressive community of Kovno that was also a centre for rebelling against the oppression of the Russian Tsarist. In fact, her co-anarchist and lover, Alexander Berkman (1870-1936) was introduced to anarchism through his readings in the Kovno library. Unfortunately, when studying the activities and writings of Emma Goldman, it can be concluded that her position in modern Jewish history has been mostly overlooked. Thus, it is logical to assume that her transnational evolution towards anarcha-feminism was inextricably impacted by her connections to various Jewish communities in the US and Europe.

First and foremost, Emma Goldman was an anarchist and most of her activism, writings, and personal convictions identify her as such. The difficulty at this point is to provide a single, neat and succinct definition of "Anarchism". The problem with this is that the very nature of anarchism is antidoctrinaire and does not propose to have a universally acceptable worldview or weltanschauung. However, "[a] 11 anarchists reject the legitimacy of external government and the State, and condemn imposed political authority, hierarchy and domination." [16] Their point of view desires a society that is decentralized, self-regulating, and relies on the works of voluntary institutions or groups made up of an egalitarian citizenry.

Since there are numerous interpretations of anarchist dogma, it is necessary at this point to describe Goldman's own personal interpretation. She defined anarchism as " $[\mathrm{t}]$ he philosophy of a new social order based on liberty unrestricted by man-made law; the theory that all forms of government rest on violent, and are therefore wrong and harmful, as well as unnecessary." [17] What made Goldman the target of American anti-socialists and fervent nationalists was her belief that the primary evil of society was the result of economic capitalism. In her essay on Anarchism she based her arguments on Marxist's history of the economic exploitation of the working class. Unlike Marxists though, she noted that all individuals in society have an important and valuable relationship with each other in order to achieve a state of social well - being. All formal organizations, governmental or religious, were considered to be the instigators of man's economic and societal enslavement. For her, the only way to eliminate the exploitation of mankind was an anarchism whose "...goal is the freest possible expression of all the latent powers of the individual." [17] Goldman was particularly harsh on religion, because she believed that all organized religions, and especially Christian religions, were historical promoters for exploiting the weaknesses of human nature. In response, anarchism became the only way by which man could liberate his mind from religious superstitions and the agitprop of government. Within this context, anarchism was the "great leaven of thought" and the only way to achieve perpetual social harmony.
Today's interpretation of Anarcha-Feminism is an outgrowth of the feminist movement of the 1960s, though its basic foundations are rooted in the anarchist movement of the late 19th and early 20th centuries. "the second wave of anarcha-feminists in the late sixties maintained that 'anarchism is the logically consistent expression of feminism' since it does not separate political activities from personal dreams of liberation." [18] Succinctly, Anarcha-Feminism views society as being made up of a patriarchal and coercive hierarchy that prevents women from being equal partners with men in national politics, society, and culture. According to Brown, "anarcha-feminism is a movement that seeks the independence of social freedoms and liberties without reliance on other individuals or groups." [19]

We do know that Emma Goldman did not approve of the first-wave feminists' push for universal suffrage, though she was totally committed to the principles that are reflected in today's tenets of Anarcha-Feminism. She agreed with the idea that "women must have the equal right in all affairs of society.... [but] I am opposed to woman suffrage on the conventional ground that she is not equal to it." [20] Her contention was that women's participation in politics would not eliminate the "poison...inherent in politics". Today, Goldman is proclaimed to be one of the founders of AnarchaFeminism who demanded the independency of women to marry whomever they wish, to possess the freedom to love whomever they desire, and to have the right of selfdetermination relative to child birth and motherhood.

\section{Geo-moments of Goldman's Anarcha-Feminism}

On Sunday, June 27, 1869, Taube Bienowitch Goldman (1837-1923) gave birth to Emma, who was the first of four children fathered by Abraham Goldman, an ultra-Orthodox Jew. This was Taube Goldman's second marriage - arranged after the death of her first husband, with whom she gave birth to two daughters - Helena (b. 1860) and Lena (b. 1862). Emma Goldman's father was chagrined by her birth seeing it as a failure of his "manhood". His frail self-opinion was further exacerbated by the fact that he had lost his wife's total inheritance from her first marriage by making poor business investments. Emma Goldman described herself as being the most rebellious of all her siblings that resulted in many whippings from her father, lacking any support and protection from her mother that probably began a lifetime of experienced misogyny and the exploitation and oppression of women at home and in the workplace.

\subsection{The First Geo-moment}

Kovno - St. Petersburg established the genesis that provided the source of Goldman's ideas pertaining to the betterment of women through her participation in anarchist activities. It is reasonable to assume that Goldman was significantly influenced by her severe childhood that lacked the freedom that most children experience during their 
formative youthful years. What was perhaps most difficult for Goldman was the lack of support and love of her father without any comfort or protection from her mother. To underscore her difficulties, she relayed an episode where her father refused to support her studies and "[i] $n$ his frenzy he threw my French grammar into the fires, shouting: 'Girls do not have to learn much! All a Jewish daughter needs to know is how to prepare gefullte fish, cut noodles fine, and give the man plenty of children." [21] As a result, Emma never resolved her hostile relationship with her father though it was lessoned as both grew older.

One of the more important individuals who helped shape Emma Goldman's personality was her grandmother with whom she had spent a significant amount of time during her early years in Kovno. It was while she was in grammar school that she started to demonstrate a streak of independence by challenging her teachers. This eventually led to her not receiving a commendation from her religion teacher that was required for admittance to further her education at town's gymnasium. What we can conjecture about Goldman's life in Kovno was that her grandmother probably recognized her independence streak and must have supported, rather than discouraged, her rebellious behaviour in school. Another interesting fact was that she "...had a certain yiches, or pride in inheritance, in hailing from Kovno." [22] This point has been overlooked by most researchers who tend to ignore the importance and context of Kovno's Jewish history, for individuals coming from Kovno believed that they were intellectually superior to other Jews. This was also seen in her compatriot and life-long Lithuanian Jewish lover Alexander Berkman who often expressed the importance that Kovno played in the Haskalah. "Goldman wrote that it was in the modest Kovno library that Berkman first acquainted himself with anarchist theory and then set off for America." [23]

Emma Goldman described how her "first erotic sensations" occurred when she was six years of age during a time when she developed a crush for a young peasant boy by the name of Petrushka. She noted that after several weeks of thinking about her Petrushka, she was awakened by her mother who caught her "touching herself" and "[in] an angry voice she cried: 'If ever I find your hand again like that, I'll whip you, you naughty child!'” [24] As Goldman entered puberty at the age of eleven, she became cognizant of the fact that men had a special effect on her. Again, her mother's reaction was anything but supportive, for when she called her mother for help while experiencing her first period, she was slapped in the face and told that "[t] his is necessary for a girl when she becomes a woman as a protection against disgrace." [24]

Emma Goldman moved to St. Petersburg at the age of fifteen and worked in a corset factory in the Hermitage Arcade. While working in St. Petersburg she developed a courtship with a young "handsome" man named Jacob Kershner (1864-1926) who was about five years her senior. When her father discovered this personal relationship, he became angry and hit her with his fists exclaiming that he would not put up with a loose daughter. Her father's behaviour, however, did not end this relationship. On one occasion, after she was plied with liquor and sexually assaulted by Kershner, she noted that "[s] trange, I felt no shame - only the great shock at the discovery that the contact between man and woman could be so brutal and so painful." [25] This first sexual experience resulted in diminishing her passion for Kershner, and that sex per se was nothing to be ashamed of. Interestingly, the couple married in 1887, but soon divorced because of his impotence and his insistence that she quit working and stay at home.

St. Petersburg also introduced Emma Goldman to the world of political protestation and physical conflict against the Imperial Tsarist government via the Russian Nihilist Movement. Goldman noted that she initially thought that the Nihilists were "black, sinister creatures", blaming them for causing her uncle's death, who in reality was part of the movement's plot to assassinate the tsar. Over time, however, she became supportive and sympathetic with the movement especially after the execution of the Nihilists who succeeded in assassinating Tsar Alexander II - a group with whom she felt "instinctive sympathy". Her learning about Nihilism was non-academic but probably exposed her to the works of Russian Nihilists such as Sophia Perovskaya (1853-1881), Nikolay Chernyshevsky 1828-1889), and the sisters Olga (1853-1917) and Vera (1885-1907) Lubotovitch. The most prominent part of Russian Nihilism "called for the destruction of contemporary values, resulting in an almost cultic devotion to the future and abhorrence of officials and wealth." [25] The ideas supporting the working class and using violence as an end are both reflective of her anarchistic and violent activities in the US.

Goldman's involvement with Russian Nihilism enabled and justified her support for the social and economic emancipation of women - giving rational and logical solutions to the maltreatment of all Russian citizens. According to Stites [26] there were four Nihilist concepts that were different from feminists thought of that time:

1. Nihilist wanted to change the world and not just the liberation of women.

2. Where feminists worked for improvement of women in society, Nihilists "insisted on total liberation from the yoke of the traditional family, freedom of mating, sexual equality... [or] personal emancipation." [27]

3. Nihilist women sought higher education abroad rather than to participate in the "slow struggle" for improvement in Russia.

4. Lastly, Nihilist women tended to avoid organized movements such as those promoted by socialists, suffragettes, and political radicals.

\subsection{The Second Geo-moment}

Russia - United States was a significant watershed moment that saw Emma Goldman become totally immersed in the American Anarchist Movement that established a sound footing towards her evolutionary path to AnarchaFeminism. Before arriving in the US, it is presumed that her involvement with St. Petersburg nihilists gave her the 
emotional and psychological strength to defy and escape her father's insistence of a domestic life for her and her sisters. When her father refused to give her permission to join her sisters in the US, she threatened to kill herself by jumping into the Neva River - he had no other recourse and relented.

Goldman first moved to Rochester NY and then to New Haven CT where she worked in a corset factory. Unsatisfied with her position, she returned to Rochester where Kershner had also moved and pressured to re-marry him after he threatened suicide. Their second marriage proved to be no better than the first and within a short period of time their marriage dissolved leading to a second divorce and disapproval of the local Jewish community in which she lived. A shunning of Goldman resulted in her final and complete break with Judaism.

The seminal event that activated Goldman's support for violence was the Chicago Haymarket Riot of 1886 that ended with the execution of seven workers who had fought for the eight-hour day. Soon after she moved to New York City and befriended one of the most influential individuals that affected her position as a leading anarchist: Johann Most (1846-1906). Most was a naturalized US citizen from Germany, who was a fervent speaker and editor of a German language anarchist newsletter. Based upon his works Goldman became a proponent of his call for "targeted acts of violence:" the assassination of political figures in order to bring about political, social, and economic change.

Most was also responsible for starting Goldman on the road as a successful speaker in spreading the ideas of exploitation of the working class by capitalists and how anarchism could be used to combat and over-throw the bourgeoisie factory owners. Initially, she was assigned to give all her speeches in Yiddish as a means for easing her fears of addressing large crowds and to give her more time to improve her English. Goldman soon found herself in the middle of a conflict supporting the eight-hour day and the improving of wages for factory workers. Based upon her experiences in Russia, she concluded that the eight-hour day and higher wages in were diversionary movements that were only part of the ultimate goal to change society as a whole. Soon after, she became involved in the Homestead Steel Strike that led to the collapse of the union movement in the US and imprisonment of her compatriot Alexander Berkman for the attempted murder of Henry Frick (1849-1919), chairman of the Carnegie Steel Company. Though she was not directly involved in the assassination attempt, her personal association with Beckman put her in the spotlight of the local police and FBI.

The nexus of her ideas about the exploitation of women workers was in a speech that she delivered in New York City's Union Square to a crowd of over 3,000 where she encouraged workers to take decisive action, "if they do not give you work, demand bread. If they deny you both, take bread. It is your sacred right!" [28] Shortly thereafter, she was arrested in Philadelphia for "inciting to riot" and transported back to New York for trial. Her arrest was based upon the inaccurate statement by observing "witnesses" who testified that she said to "take everything by force." Goldman, however, had the support of Nellie Bly (1864-1922) who wrote that "And so I left the little Anarchist, the modern Joan of Arc, waiting patiently in the Tombs [for] her friends. Though the evidence presented did not support her guilt of inciting a riot, the jury found her guilty..." [29] Unfortunately the guilty verdict against her was impacted by the bombastic testimony of Detective-Sargent Charles Jacobs, [30] that resulted in her sentencing to Blackwell's Island Penitentiary for one year.

Goldman considered life in Blackwell to be dehumanizing "[m] ore harrowing still was the daily degradation of being forced to marching lock-step to the river, carrying the bucket of human excrement accumulated during twenty-four hours." [31] She was soon put in charge of the women's sewing shop where she was encouraged to "get better results" from the women working under her, but refused and won the support of her co-prisoners. The position that proved to be significant in her trajectory towards a anarcha-feminist was her work in the prison hospital under the "huma direction of a Dr. White who responded to the crime she was convicted of by saying "Inciting to riot, Piffe! I don't believe you could hurt a fly." [32] When offered the position as a nurse, she hesitated, but she was eventually persuaded since there was no one else that had any related medical training. Within a short period of time she totally immersed herself in nursing activities stating that "I loved my job". Due to her expertise, she was put in charge of the hospital ward within a short period of time.

While at Blackwell, Goldman observed numerous instances of discrimination by the head matron who had a "violent dislike" for anyone who was not Anglo-Saxon, "[h] er special targets were the Irish and the Jews." [33] There was also a softer side of Goldman when one of her patients died: being responsible to prepare her for "the last journey", Goldman went to extra effort to make sure that her deceased patient would appear as beautiful as possible. Based upon her prison studies, activities, and medical responsibilities she now possessed competencies that provided her with a new path for support herself beyond speaking engagements. As a "nurse" her preferred area of work was midwifery and massage, two specializations that were not available in any American nursing programs.

\subsection{The Third Geo-moment}

United States - Vienna came about after Emma Goldman was released from prison and her new-found goal in working as a licensed nurse. It is argued in this paper that this last Geo-moment served as the tipping point in her evolution as an anarcha-feminist. Immediately after she gained her freedom, Goldman was surprisingly greeted by a large multiethnic crowd that had gathered to show their support for her and her anarchistic activities. To the supporting polyglot audience, she spoke that "[i] $f$ the representatives of your Government intend to prosecute women for talking, they will have to begin with [your] mothers, wives, sisters, and sweethearts, for they will never stop women from talking." [34] 
Shortly after her release from Blackwell, Goldman began working as a practical nurse who was sent the private patients of Dr. Julius Hoffman of St. Mark's Hospital. With the help of Dr. White, Goldman excitingly accepted employment at the new Beth-Israel Hospital on East Broadway in New York City, of which she noted, "I loved my profession and I was able to earn more money than at any time previously." [35] As a practicing nurse, she soon realized that without a nursing diploma it would be impossible to obtain a position as a trained nurse, for "[p] ractical nurses were paid and treated like servants." [36] Though Dr. Hoffman, Goldman was provided with the "great opportunity" to travel to Vienna to further her nursing education. Before proceeding to Vienna, Goldman traveled to London to what she thought was the most significant part of her travels, the opportunity to meet and talk with world-renowned anarchists William Benham (1859-1944), Peter Kropotkin (1842-1921), and Alfred Marsh (1858-1914). The one person who excited her most was when she met the French female anarchist Louise Michel (1830-1905) who was routinely referred to in European newspapers as "red she-wolf" (la Louve rouge).

As much as she enjoyed London, Goldman had to depart for Vienna to begin her coursework on the first of October 1895. Her first impressions of the Austrian-Hungarian capital city was both exciting and fascinating. She was impressed with the city's tree-lined promenades and parks, for " $[\mathrm{t}]$ here was colour here, life and joy. I longed to be part of it...[b] ut I had come for another purpose... [and] could not afford to be distracted." [37] At the University of Vienna she chose to concentrate her studies in midwifery and the diseases of children. Within the hospital itself, she found herself in the company of world-renowned professors and researchers who were responsible for thousands of patients and oversaw a large medical staff of nurses, doctors, and care-givers. Another aspect of her medical education that surprised her were the presents of other "Jewish girls" who had come from Russia and Palestine.

Due to her reputation as a violent anarchist, Goldman had to hide her true identity and traveled to Vienna under the assumed name "Mrs. E. G. Brady." This, however, did not stop her from meeting "my comrades" in private and secret locations - always aware of the potential for being exposed she was in constant fear of expulsion from the university that would end of her nursing education. When Goldman began her studies, she was informed by fellow-students that there was a young professor, Sigmund Freud (1856-1939), whose study of sexuality was at the cutting edge of research. However, she was not able to enrol in any of his lectures because only physicians and holders of "special cards" were admitted. In lieu of Freud's course, it was suggested that she should enrol in a course conducted by Carl-Bernhard Brühl (1820-1899) who was a professor and director of the Zootomic Institute. Unlike other university professors, Brühl often conducted scientific lectures without charging fees, and even more controversial, had opened his lectures to female students. [38] Of particular interest to Goldman were his lectures on sex problems. Eventually, as a registered student in Brühl's course, she gained possession of a proper card to enrol into Freud's course. Emma Goldman had always faced the problems of misogyny, and for the first time these barriers were removed, or at least minimized, setting in motion her refined ideas of personal liberation.

While sitting in Brühl's lectures, Goldman noted that " $[\mathrm{h}]$ e talked about 'yearnings,' 'Lesbians,' and other strange topics [my italics]." [39] It is fascinating to note that Goldman described many of the other students sitting in Brühl's course as being "strange", in that there were a significant number of effeminate men and women who were "distinctly masculine." Thus, within the University's academic environment she became exposed to and part of the Lesbian and Gay student community for the first time in her life. During her attendance in Freud's lectures, she became aware of the uniqueness and attributes of homosexuals. "For the first time I grasped the full significance of sex repression and its effect on human thought and action." [40] Goldman credited Freud for helping her to understand and appreciate herself and her personal needs, part of which enabled her to respect the uniqueness of all minority and oppressed groups and to reject the idea that these groups had "depraved minds" and were thusly "impure".

In the end, she had no problems passing her course of study and was the "proud holder of two diplomas" with specialties in midwifery and nursing. Based upon her experiences at the University of Vienna, Emma Goldman's perceptions and understanding of sexuality and feminism matured her philosophy about the rights of women and how to best fight against society's misogynic attitudes. Hence, it is conjectured that upon completing her medical studies, that she had progressed from an "pure" anarchist to that of an anarcha-feminist.

\section{Emma Goldman an Anarcha-Feminist}

After Emma Goldman's return from Vienna, there was a noticeable change in the character of her activities, speeches, and writings. By 1919, J. Edgar Hoover had declared her, along with Alexander Berkman, as "two of the most dangerous anarchists in America" [41] resulting in the attack on her legal rights as a dissenter and status as a naturalized US citizen. She, however, continued to have her supporters within the American Progressive Movement who "...defended her controversial public speech by appeal to constitutionally guaranteed individual freedoms." [42] Goldman tended to strike fear in the hearts of society due to her outspoken views on the rights and liberties that had been denied to women. "Goldman's centering of sexual freedom at the heart of revolutionary vision and practice is part of a long tradition of sexual politics, one which struggles to make sense of how productive and reproductive labour come together." [43]

\subsection{Birth Control \& the Comstock Law}

Emma Goldman's foray into the arena of birth control and the right for women to dictate their own sexual desires 
propelled her to the front lines (and front pages) of women's progressive feminist movements. Unfortunately, her activities did not endear her with the leadership of the American Suffragette Movement who tended to ignore her, especially when it came to issues of a woman's right to control what happens to their body. Unlike Europe, her US lectures on birth control raised fears about her potential arrest for violating the Comstock Law. To avoid arrest, she designed her talks within the context of women's personal and social struggles rather than birth-control methods and practices. The reason for this was that the 1873 Comstock Act was used to halt the dissemination of birth-control information via the U. S. Postal Service under the argument that the topic was obscene, vulgar, indecent, and filthy. Goldman justified her social struggles approach because she "was so continually on the brink of prison because of my general activities that it seemed unjustifiable to court extra trouble." [44]

Emma Goldman was inspired by Margaret Sanger (18791966), who was recognized as "the" renowned advocate of birth control because she "understood the role of poverty and the importance of a woman's freedom to choose whether or not she wanted, or could provide for, a child." [45] Goldman was quite aware of the potential for her arrest because Sanger had encountered legal difficulties in using the U. S. Postal Service to disseminate her publication The Woman Rebel, that resulted in the arrest of her husband William Sanger (1873-1961) who gave a copy of Rebel to a Comstock agent. Goldman decided that she had to continue her work in supporting this basic right of women. In her lecture at the Sunrise Club of New York City, she spoke to a record number of six hundred attendees. Significantly, the majority present at her birth control lectures represented a diverse spectrum of professions such as lawyers, physicians, and a contingent of individuals having "liberal views". Even though she did not discuss birth control methods and practices, many of the Club's membership had expected her to be arrested. About that night she simply stated: "No arrest followed." [46]

\subsection{Rights of Lesbians and Gays}

Today, Emma Goldman is seen as one of the initial public supporters of the LGBT community, and rightly so. In addition to speaking about reproductive issues, Goldman also gave a number of talks dealing with lesbian and gay rights. She noted that " $\mathrm{t}]$ he men and women who [came] to see me after my lectures on homosexuality confided to me their anguish and their isolation." [47] - a situation that deeply troubled her. In fact, she noted that these individuals tended to possess a "finer grain" than members of society who wanted to "cast them out." One of the most intellectual aspects of Goldman's lectures was the justification of the individual rights of lesbians and gays within the theories of anarchy. Seeing the discrimination and legal harassment of this group, anarchism was no longer viewed as an esoteric theory, "it was a living influence to free us from inhibitions, internal no less than external, and from the destructive barriers [my italics] that separate man from man." [48]
Unlike today, topics dealing with homosexuality during the late nineteenth and early twentieth centuries were rarely discussed. Based upon her personal Geo-moment experiences, Goldman took the stance that homosexual groups tended to be more creative than the general public, and perhaps more importantly, they had a significant amount of courage in dealing with their situation. As a group, she saw lesbians and gays as minorities who were discriminated against and wrongly persecuted by the law and society. The vast majority of her lectures approached the topic within the purview of psychology and argued against the idea of a medical disease producing degenerate behaviour. Unlike feminists of her time, she was proud of her personal friendship with "bohemian lesbians" such as Margaret Anderson (1886-1973) and Ellen Kennan (1871-1950), both of whom promoted Goldman's lectures about the importance of individual liberties and rights.

\subsection{Mother Earth}

Emma Goldman found that she needed a new method, other than giving speeches, to disseminate her ideas. This resulted in the publishing the anarchist journal Mother Earth, in which she served as editor and writer during its elevenyear history (1906-1917). 1911 had become a watershed moment due to the fact that she wrote three important articles about the second-class status of women, establishing her as a first rate intellectual of feminist issues.

"The Hypocrisy of Puritanism"

In this essay Goldman attacked the religious nature of puritanism as the cause of forcing women into marriage and a life of dullardism. She pointed to the lives of Mary Wollstonecraft (1759-1797) and George Eliot (1819-1880) who were the "freest women" of their time, but who were still forced into a "lie" of conventional marriage. "Puritanism no longer employs the thumbscrews and lash; but it still has a most pernicious hold on the minds and feelings of the American people," [49] otherwise how could one justify and explain the invasive power of the Comstock Act. She believed that the puritanical American society was a perversion and a crime against the natural behaviour of humans. "Absolute sexual continence is imposed upon the unmarried woman, under pain of being considered immoral or fallen, with the result of producing neurasthenia, impotence, depression and a great variety of nervous complaints." [50] American puritanism was worse than Czarist Russia because "America, [had become] the stronghold of Puritanic eunuchs." [51]

\section{(i). "The Traffic in Women"}

This second, and perhaps more significant essay, was Goldman's article attacking the trafficking of women for sex that she described as the trading of "white slaves". Here, she accused the US Government of supporting the practice of sending white prostitutes to the Panama Canal project because "[s] ociety considers the sex experiences of a man as attributes (my italics) of his general development, while similar experiences in the life of a woman are looked upon as 
a terrible calamity." [52] She described women as being a "sex commodity" where they are kept in the dark and uneducated in the meaning and importance of sex. "It is due to this ignorance that the entire life and nature of the girl is thwarted and crippled." [53]

One of the more important assertions made by Goldman was her contention that women who marry for money and social status were equivalent to prostitutes because they would be "absolutely bound to her master." In effect, she concluded that unlike married women, prostitutes never sign away their rights to another person and always retains her personal human rights. Referring to her Jewish heritage, she said that there was a false myth that had been developed in Europe and America that "proclaim [ed]...that the Jews furnish the largest contingent of willing prey." [54] As evidence against this myth, she note that Jewish girls are not adventurous, and do not travel without being accompanied by a relative. Goldman believed that the only way to solve the problem of white slavery was to assure that public opinion be steered by education and hard scientific facts. An educated public would be able to recognize the fallacy of a "better than thou" attitude and recognize that prostitution is the result of a country's social conditions. "As to a thorough eradication of prostitution, nothing can accomplish that save a complete transvaluation of all accepted values especially the moral ones--coupled with the abolition of industrial slavery." [55]

\section{(ii). “Woman Suffrage"}

In this third article that Goldman explained her position against the American Suffrage Movement. Specifically, she stated that the suffragette movement in America was based on all Christian religions that condemned women to a "life of an inferior, and slave". The notion of a home "blinds woman to the price she would have to pay as wife, mother, and house keeper. Yet woman clings tenaciously to the home, to the power that holds her in bondage." [56] Thus, the objectives of American suffragettes, being based upon a foundation of Christian teachings, would not improve the status and quality of life of all women nor end misogynism.

Even countries with universal suffrage (Australia and New Zealand), there still existed a "Puritanical double standard". She conceded that universal suffrage would guarantee their legal rights to maintain property ownership, but totally ignored women who had no property. Additionally, "of what avail is that right to the mass of woman without property, the thousands of wage workers, who live from hand to mouth?" [57] Of particular concern to Goldman was the bigoted view that "proper women" and suffragettes had about the plight of woman who were forced into prostitution and had become "disfranchised [by] her sisters of the street, and declared all women of 'lewd character' unfit to vote." [58]

\section{Reactions to Emma Goldman's Positions on Feminism}

Most people today associate Emma Goldman with the "most dangerous" moniker associated with her violent anarchist activities. In reality, she can be described as the person who laid the groundwork for recognizing various women's issues that included birth control, sexual freedom, lesbian and gay rights, and improving the working conditions of both men and women. To say that she was ahead of her time on important political and social issues would be an understatement. Additionally, her zealous speeches and extremely aggressive tactics has resulted in her being recognized today as the first anaracha-feminist. "Goldman's bold confrontations with authorities constituted a kind of anarchist parrhesia, fearless, speech, a relentless truth-telling practice that risked her own security in pursuit of her 'beautiful ideal."' [59] She always challenged the limits of the parrhesiastic contract where public criticism of governments are permitted.

Overall, Goldman had many successes that included her ability to reach thousands of working people, creation of free speech leagues, establishment of the anarchist newsletter Mother Earth, free schools, prison reforms, and attempts to improve the economic, political, and societal position of women. As successful as she was, there have been a number of contemporary feminists who criticized her for differences between what she preached and what she practiced. For example, Marso noted that Goldman's life and work were "example [s] of how even the most radical and forwardthinking women can get trapped by the contemporary patriarchal norms under which they live, often even unconsciously internalizing these norms." [60] Additionally, her biographer, Alice Wexler, concluded that the discrepancy between Goodman's remarks and personal life should have resulted in revising her positions on marriage and love due to "her own personal failure to live out her vision of an open relationship." [61] In response to these and other criticisms against Goldman, Ferguson defended her by noting that the reason for these arguments was that Goldman herself continually questioned what she advocated in her writings as well as in her anarchist actions. "Goldman often invited precisely the kinds of criticism levelled by Wexler and Marso through her insistence on utter, unwavering consistency between her anarchist beliefs and her ways of life." [62]

There is one more explanation for Goldman's berating herself when arguing for open and guiltless sex and love: she was not a strict and confining philosophic ideologue, but a person who was always questioning the effectiveness of her activities. As Emma Goldman herself admitted, there were always discrepancies between what she said versus what she practiced, but from a logical point of view, her personal conflicts in no way minimizes her effectiveness and impact on the feminist movement to this day.

\section{Conclusions}

The use of a transnational methodology proved to be effective in illustrating the development of Emma Goldman's ideas that addressed the problems associated with women's issues in the home, workplace and society. Within the context of Geo-moments, it was described how her unique 
positions on feminism evolved from a novice anarchist and nihilist to that of a mature and effective anarcha-feminist. "Goldman was a pariah for the authorities, eventually included in their political arrangements through the forced exclusion of exile." [63] However, it is without question that Goldman's writings and activities have proven to be influential to both contemporary feminist and the LGBT community. In fact, many of the causes that she fought for such as the right of women to make decisions about their own body and the end of being exploited by being paid an "under-valued" income are still at the forefront of contemporary women's issues. Goldman's critics may be correct that she was not the best example of a "true" feminist must, but her influence on current economic and social issues has been significant. Her anarcha-feminist activities led to combating the exploitation and misogyny. What makes Goldman different from her contemporaries was that she saw the emancipation of women as an integral part for advancing revolutionary action. [64].

\section{References}

[1] Emma Goldman, Anarchism and Other Essays, First Edition, (Lexington: Will Jonson, 2013), p. 93.

[2] Emma Goldman, Living My Life, Volume One, 1931, (New York: Dover Publications, Inc., 1970), p. 12. Noted from this point on as $L M L$, v. 1 or v. 2.

[3] See: 'The Hypocrisy of Puritanism', 'The Traffic in Women', \& 'The Tragedy of Woman's Emancipation' in Anarchism and Other Essays.

[4] The term "geo-moment" pertains to the influence or effect that geographic movements beyond the concept of state borders had on Goldman's evolution as an anarcho-feminist.

[5] C. A. Bayly, Sven Beckert, et al. 'AHR Conversations: On Transnational History', American Historical Review, (vol. 111 no. 5, December 2006), p. 1459.

[6] Amrita Basu, 'Globalization of the Local/Localization of the Global Mapping Transnational Women's Movements', Meridians, (vol. 1 no. 1, Autumn 2000), pp. 68-84.

[7] Joseph S. Nye Jr. and Robert O. Keohane, 'Transnational Relations and World Politics: An Introduction', International Organization, (Vol. 25 No. 3, Summer 1971), pp. 329-349.

[8] John M. Owen IV, The Clash of Ideas in World Politics: Transnational Networks, States and Regime Change, 15102010, (Princeton NJ: Princeton University Press, 2010).

[9] Michael Goebel, 'Una Biografia Entre Espacios: M. N. Roy. Del Nacionalismo Indio al Comunismo Mexicano', Historia Mexicana, (Vol. 62 No. 4 (248), Abril-Junio 2013), pp. 14591495.

[10] John D. Bies, 'Transnational Perspective of the Evolution of Rosa Luxemburg's Theory of the Mass Strike, Critique, (Vol. 46 No. 2, May 2018), pp. 185-219.

[11] Rebecca Korbin, 'Currents and Currency: Jewish Immigrant "Bankers" and the Transnational Business of Mass Migration, 1873-1914, Transnational Traditions: New Perspectives on
American Jewish History, Ava F. Kahn and Adam D. Mendelsohn, Editors, (Detroit, 2014), p. 90.

[12] Amrita Basu, 'Globalization”, pp. 68-84.

[13] Michael Berkowitz, 'Emma Goldman's Radica Trajectory: A Resilient "Litvak" Legacy?', Journal of Modern Jewish Studies, (Vol. 11 No. 2, August 2012), p. 243.

[14] Hadassa Kosak, Cultures of Opposition: Jewish Immigrant Workers, New York City, 1881-1905 (Albany NY: State University of New York Press, 2000).

[15] Mark N. Ozer, The Litvak Legacy, (Xlibris, 2009), p. 145.

[16] Peter Marshall, Demanding the Impossible: A History of Anarchism, (Oakland CA: PM Press, 2010), p. 3.

[17] Emma Goldman, 'Anarchism and Other Essays', Mother Earth Publishing Association, (New York-London, 1910).

[18] Marshall, History of Anarchism, p. 556.

[19] Susan L. Brown, 'Beyond Feminism: Anarchism and Human Freedom', in Reinventing Anarchy, Again, Howard J. Ehrlich, Editor, (San Francisco CA: AK Press, 1996), p. 208.

[20] Emma Goldman, 'Woman Suffrage', Mother Earth Publishing Association, (New York-London, 1911), p. 202.

[21] Emma Goldman, $L M L$, v. 1, p. 12.

[22] Michael Berkowitz, 'Emma Goldman's Resilient "Litvak" Legacy?', p. 247.

[23] Michael Berkowitz, 'Emma Goldman's Resilient "Litvak" Legacy?', p. 248.

[24] Emma Goldman, $L M L$, v. 1, p. 21.

[25] Emma Goldman, LML, v. 1, p. 23.

[26] Olga Vishnyakova, "Russian Nihilism: The Cultural Legacy of the Conflict Between Fathers and Sons", Comparative and Continental Philosophy, (Vol. 3 No. 1, 2011), p. 103.

[27] Richard Stites, The Women's Liberation Movement in Russia: Feminism, Nihilism, and Bolshevism, 1860-1930, (Princeton NJ: Princeton University Press, 1990), pp. 89-114.

[28] Philip Forner, History of the Labor Movement in the United States, Vol. 2: From the Founding of the AFof L to the Emergence of American Imperialism, (New York: International Publishers, 1955).

[29] Emma Goldman, $L M L$, v. 1, p. 123.

[30] Nellie Bly, "Nelly Bly Again: She Interviews Emma Goldman and Other Anarchists", New York World, (September 17, 1893).

[31] Jacobs did offer to release Goldman and drop all charges on their train ride to New York City if she would turn informant against other anarchists, to which she replied by throwing a glass of water in his face.

[32] Emma Goldman, $L M L$, v. 1, p. 134.

[33] Emma Goldman, $L M L$, v. 1, p. 137.

[34] Emma Goldman, $L M L$, v. 1, p. 138.

[35] "Hailed Emma Goldman", the New York World, August 20, 1894. 
[36] Emma Goldman, $L M L$, v. 1, p. 157.

[37] Emma Goldman, $L M L$, v. 1, p. 161.

[38] Emma Goldman, LML, v. 1, p. 170.

[39] It was noted by Paul Bishop in Analytic Psychology and German Classical Aesthetics: Geothe, Schiller, and Jung, Vol. 2: The Constellation of the Self, (New York: Taylor and Francis, 2008) that Sigmund Freud decided to enter medical school after reading Goethe's Die Natur.

[40] Emma Goldman, LML, v. 1, p. 173.

[41] J. Edgar Hoover, "Memorandum for Mr. Creighton," U. S. Dept. of Justice (23 August 1919).

[42] Kathy E. Ferguson, "Discourses of Danger: Locating Emma Goldman”, Political Theory, (Vol. 36, No. 5, October 2008), p. 373 .

[43] Clare Hemmings, "Sexual freedom and the promise of revolution: Emma Goldman's passion," Feminist Review, (106, February 2014), p. 43.

[44] Emma Goldman, LML, v. 2, p. 553.

[45] Candice Falk, editor, Emma Goldman: A Documentary History of the American Years, Volume 3: Light and Shadows, 1910-1916, (Stanford CA: Stanford University Press, 2012), pp. 86-87.

[46] Emma Goldman, $L M L$, v. 2, p. 554.

[47] Emma Goldman, $L M L$, v. 2, p. 555.

[48] Emma Goldman, $L M L$, v. 1, p. 556.

[49] Emma Goldman, "The Hypocrisy of Puritanism", (1911), in Anarchism and Other Essays, 2013 Edition, (New York), p. 85.
[50] Emma Goldman, $L M L$, v. 1, p. 88.

[51] Emma Goldman, $L M L$, v. 1, p. 89.

[52] Emma Goldman, "The Traffic in Women", (1911), in Anarchism and Other Essays, 2013 Edition, (New York), p. 96.

[53] Emma Goldman, $L M L$, v. 1, p. 97.

[54] Emma Goldman, $L M L$, v. 1, p. 101.

[55] Emma Goldman, $L M L$, v. 1, p. 103.

[56] Emma Goldman, "Women Suffrage", in Anarchism and Other Essays, (1911), 2013 Edition, (New York), p. 105.

[57] Emma Goldman, $L M L$, v. 1, p. 108.

[58] Emma Goldman, LML, v. 1, p. 109.

[59] 2 Kathy E. Ferguson, "Discourses of Danger: Locating Emma Goldman”, Political Theory, (Vol. 36 No. 5, October 2008), p. 738 .

[60] Lori JoMarso, "A Feminist Search for Love: Emma Goldman on the Politics of Marriage, Love, Sexuality, and Feminine", in Feminist Interpretations of Emma Goldman, Penny Weiss \& Loretta Kensinger (editors), (University Park: Pennsylvania State UniversityPress, 2007), p. 73.

[61] Alice Wexler (1984), Emma Goldman: An Intimate Life, (New York: Pantheon), p. 155.

[62] Kathy E. Ferguson, op. cit., p. 735.

[63] Emma Goldman, $L M L$, v. 1, p. 753.

[64] Clare Hemmings, "Sexual freedom and the promise of revolution: Emma Goldman's passion”, Feminist Review (No. 16, 2014), pp. 43-59. 